\title{
PROFITABILITAS, UKURAN PERUSAHAAN DAN INTELLECTUAL CAPITAL TERHADAP NILAI PERUSAHAAN
}

\author{
Alma Nur Aulia \\ (Program Studi Manajemen, Fakultas Ekonomika dan Bisnis Universitas Kanjuruhan, Malang) \\ e-mail: unikama.ac.id \\ Rita Indah Mustikawati \\ Sugeng Hariyanto \\ (Program Studi Manajemen, Fakultas Ekonomika dan Bisnis, Universitas Kanjuruhan, Malang)
}

\begin{abstract}
ABSTRAK: Penelitian ini bertujuan untuk menganalisis pengaruh profitabilitas, ukuran perusahaan dan intellectual capital terhadap nilai perusahaan. Profitabilitas diukur dengan rasio return on equity (ROE). Ukuran perusahaan diukur dengan Logaritma natural total aset. Intellectual capital diukur dengan rasio value added intellectual efficiency method (VAIC ${ }^{\mathrm{TM}}$ ) dan nilai perusahaan diproksi dengan Price book value (PBV). Populasi dalam penelitian ini adalah perusahaan food and beverage yang go public di Bursa Efek Indonesia. Teknik pengambilan sampel digunakan dengan purposive sampling. Periode pengamatan dilakukan pada 20142018, dengan total sampel 11 perusahaan. Jumlah data observasi adalah 44 pasang data. Teknik analisis data menggunakan regresi linier berganda. Hasil penelitian menunjukkan bahwa secara simultan profitabilitas, ukuran perusahaan dan intellectual capital terhadap nilai perusahaan. Profitabilitas berpengaruh terhadap nilai perusahaan dengan arah negatif. Ukuran perusahaan tidak berpengaruh terhadap nilai perusahaan. Intellectual capital berpengaruh terhadap nilai perusahaan dengan arah positif.
\end{abstract}

Kata kunci - Profitabilitas, Ukuran Perusahaan, Intellectual Capital dan Nilai Perusahaan.

\section{PENDAHULUAN}

Pertumbuhan ekonomi di Indonesia ditopang oleh banyak sektor, salah satunya adalah sektor food and beverage. Perusahaan ini berperan penting sebagai penyumbang pertumbuhan ekonomi di Indonesia. Menteri Perindustrian, Airlangga Hartono mengatakan "pada tahun 2018 dari lima investasi sektor industri, paling besar dari sektor food and beverage sebesar Rp.29,14 triliun dan memiliki porsi kontribusi terbesar terhadap Produk Domestik Bruto (PDB) nasional yakni 6,33\% pada semester I 2018" (Kompas.com, 2018). Data tersebut menunjukkan bahwa sektor food and beverage memiliki kontribusi dalam pertumbuhan ekonomi di Indonesia. Setiap perusahaan harus berupaya untuk terus berinovasi dengan beradaptasi terhadap setiap perubahan dalam proses bisnisnya agar meningkatkan nilai perusahaan secara berkesinambungan. Investor akan menilai baik suatu perusahaan yang memiliki nilai perusahaan yang tinggi, Nilai perusahaan mencerminkan total aset yang dimiliki oleh perusahaan apabila perusahaan dijual yang tergambar dalam harga saham perusaahaan. Oleh sebab itu nilai perusahaan sangat erat kaitannya dengan minat investor terhadap suatu perusahaan.

Perusahaan akan selalu dihadapkan pada keadaaan dimana terjadi kenaikan bahkan penurunan nilai perusahaan. Naik turunnya harga saham menjadi isu menarik yang berkaitan dengan nilai perusahaan. Adapun kasus penurunan harga saham di perusahan food and beverage yakni perusahaab dengan kode MLBI yakni turun tipis 0,67 persen ke Rp 14.900 per saham pada sesi 1 perdagangan jumat, 23 Februari 2018. (Bareksa, 2018). Penurunan harga saham juga terjadi pada perusahaan dengan kode INDF yakni turun 2.71 ke level Rp 6,275 per saham. (CNCB, 2018). 
Berdasarkan kasus diatas terkait naik turunnya nilai perusahaan, perusahaan harus mampu menjaga nilai perusahaan dalam kondisi yang baik. Nilai perusahaan yang yang baik adalah gambaran dimana perusahaan mampu mendatangkan keuntungan bagi investor, sebaliknya jika nilai perusahaan menurun bahkan anjlok pada titik terendah akan merugikan investor, hal ini tentu akan mempengaruhi kelangsungan dimasa mendatang.

Nilai perusahaan dipengaruhi oleh beberapa faktor diantaranya profitabilitas. Profitabilitas merupakan kemampuan perusahaan dalam menghasilkan laba baik dengan total penjual, aset dan modal saham pada prusahaan. Perusahaan akan berusaha keras dalam memaksimalkan sumber daya yang ada untuk memaksimalkan laba perusahaan. Semakin tinggi perusahaan dalam menghasilkan laba akan meningkatkan nilai perusahan itu sendiri. Perusahaan memperoleh laba yang besar, maka perusahaan akan dianggap memiliki daya tarik bagi investor karena profitabilitas adalah hasil yang diperoleh melalui dana yang diinvestasikan oleh para investor.

Selain profitabilitas, ukuran perusahaan dapat mempengaruhi nilai perusahaan (Indriyani, 2017). Ukuran perusahan merupakan ukuran besar kecilnya suatu perusahaan yang dapat dilihat daro total asset perusahaan. Investor beranggapan bahwa ukuran perusahaan yang besar menunjukan nilai perusahaan yang tinggi dan sebaliknya, ukuranse perusahaan yang kecil menunjukan nilai perusahaan yang rendah. Namun dilihat pada kasus yang terjadi pada tahun 2018 dimana MLBI merupakan perusahaan dengan ukuran menengah dan INDF merupakan perusahaan dengan ukuran besar, keduanya sama-sama mengalami penurunan harga saham. Oleh karena itu, ukuran perusahaan besar atau kecil bukanlah ukuran investor dalam menilai prospek perusahaan.

Perusahaan dituntut untuk mengubah cara mereka dalam menjalankan bisnisnya agar dapat bersaing dengan perusahaan lainya. Perusahaan dituntut untuk mengubah strategi bisnisnya yang didasarkan pada tenaga kerja (labour-based business) menjadi bisnis yang berdasarkan pengetahuan (knowledge based business) (Afifah, 2014). Pemenuhan modal atau dana dianggap masih belum cukup, hal yang tidak kalah penting adalah pemenuhan kebutuhan tenaga kerja dengan kapabilitas dan pengetahuan yang mumpuni. Seperti yang telah disampaikan Menteri Perindustrian bahwasanya bisnis sekarang harus menerapkan intellectual capital agar mampu menciptakan nilai tambah sehingga memberikan keunggulan kompetitif bagi perusahaan. Perhatian terhadap intellectual capital meningkat karena modal ini digunakan sebagai alat untuk menentukan nilai perusahaan. Dengan memusatkan perhatian pada intellectual capital perusahaan diharapkan dapat meningkatkan nilai perusahaan.

Peneliti memperkuat untuk melakukan penelitian ini dengan adanya perbedaan penelitian yang dilakukan oleh Suparno dan Ramadini (2017) menunjukan intellectual capital mempengaruhi nilai perusahaan sedangkan penelitian yang dilakukan oleh Lestari dan Candra (2016) menunjukan intellectual capital tidak mempengaruhi nilai perusahaan. Penelitian Dewa, Putra, Fachrurrozie dan Utaminingsih (2014), Sucuahi \& Cambarihan (2016) dan Indriyani (2017) menunjukan profitabilitas mempengaruhi nilai perusahaan sedangkan penelitian Nugrohoa dan Abdani (2018) menunjukan hasil yang berbeda yakni profitabilitas tidak mempemgaruhi nilai perusahaan.

Berdasarkan fenomena dan research gap yang telah dijelaskan diatas, peneliti tertarik untuk melakukan penelitian tentang pengaruh profitabilitas, ukuran perusahaan dan intellectual capital pada perusahaan Food and Beverage di Bursa Efek Indonesia periode 2014-2018.

Tujuan dari penelitian ini adalah: 1) Mengetahui pengaruh profitabilitas, ukuran perusahaan dan intellectual capital terhadap nilai perusahaan, 2) Mengetahui pengaruh profitabilitas terhadap nilai perusahaan, 3) Mengetahui pengaruh ukuran perusahaan terhadap nilai perusahaan dan 4) Mengetahui pengaruh intellectual capital terhadap nilai perusahaan.

\section{TINJAUAN PUSTAKA}

\section{Teori Sinyal (Signaling Theory)}

Brigham dan Houston (2010) menyatakan "teori signal adalah suatu tindakan yang dilakukan perusahaan dalam rangka memberi petunjuk bagi investor tentang bagaimana manajemen memandang prospek perusahaan". Perusahaan akan memberikan informasi terhadap kondisi perusahaan, semakin baik informasi yang diberikan akan mempengaruhi minat investor terhadap saham perusahaan dan sebaliknya jika informasi tentang perusahaan tidak terlalu baik maka investor akan mengurungkan niat untuk membeli saham perusahaan. 


\section{Profitabilitas, Ukuran Perusahaan Dan Intellectual Capital Terhadap Nilai Perusahaan}

Informasi tentang perusahaan akan digunakan investor dalam membandingkan perusahaan yang satu dengan yang lain untuk pengambilan keputusan.

\section{Resource Based Theory (RBT)}

"Resource Based Theory (RBT) berfokus pada konsep atribut keunggulan yang difficult to imitate sebagai sumber kinerja yang unggul dan keunggulan kompetitif" (Barney, 1986; Madhani, 2009). Dalam teori ini dikatakan bahwa jasa produktif yang berasal dari sumber daya perusahaan memberikan karakter unik bagi perusahaan yang bersangkutan atau disebut heterogen. Pengukuran kinerja tradisional yang biasa terdapat pada laporan keuangan, tidak dapat mencerminkan secara penuh intangible resource dalam perusahaan. Perusahaan akan memiliki keunggulan kompetitif dan mampu bersaing dengan kompetitor jika suatu perusahaan dapat memanfaatkan sumber daya yang ada dengan semaksimal mungkin.

\section{Nilai Perusahaan}

"Nilai perusahaan adalah nilai jual sebuah perusahaan sebagai suatu bisnis yang beroperasi" (Sartono, 2014). Nilai perusahaan mencerminkan total aset yang dimiliki oleh perusahaan apabila perusahaan dijual yang tergambar dalam harga saham perusaahaan. Nilai perusahaan semakin baik akan menambah minat investor untuk berinvestasi pada perusahaan. Karena nilai perusahaan yang tinggi menggambarkan kemakmuran pemegang saham dan pasar juga percaya perusahaan mempunyai prospek yang bagus kedepannya.

\section{Profitabilitas}

Profitabilitas adalah ukuran kemampuan perusahaan dalam menciptakan keuntungan baik berdasarkan total aset, total modal ataupun total pembelian. Besarnya tingkat profitabilitas menunjukan kinerja perusahaan yang baik dimana akan mempengaruhi minat investor.

\section{Ukuran Perusahaan}

Ukuran perusahaan adalah cerminan terhadap ukuran besar atau kecil suatu perusahaan yang sering dilihat dari total aset perusahaan. "Ukuran perusahan merupakan ukuran besar kecilnya suatu perusahaan yang ditunjukan atau dinilai oleh total asset, total penjualan, jumlah laba, beban pajak dan lain-lain" (Brigham dan Houston, 2010).

\section{Intellectual Capital}

Intellectual capital atau sering di sebut dengan modal intelektual adalah suatu aset tidak berwujud mampu menciptakan keunggulan kompetitif pada perusahaan dan modal ini merupakan modal unik yang menjadi ciri khas perusahaan sehingga sangat susah dittru oleh perusahaan lain. Intellectual capital mengacu kepada sebuah pengetahuan dan kemampuan yang dimiliki oleh suatu kolektivitas sosial seperti organisasi, praktek professional atau juga komunitas intelektual. Modal intelektual terdiri dari tiga komponen yakni modal manusia, modal konsumen dan modal organisasi.

\section{HIPOTESIS}

\section{Profitabilitas Terhadap Nilai Perusahaan}

Profitabilitas adalah ukuran kemampuan perusahaan dalam menciptakan keuntungan baik berdasarkan total aset, total modal ataupun total pembelian. Besarnya tingkat profitabilitas menunjukan kinerja perusahaan yang baik dimana akan mempengaruhi minat investor. Minat investor yang tinggi akan menyebabkan permintaan terhadap saham perusahaan tinggi sehingga menyebabkan nilai perusahaan tinggi. Penelitian Sucuahi dan Cambarihan (2016) menunjukan profitabilitas mampu mempengaruhi nilai perusahaan.

Hipotesis 1: Profitabilitas berpengaruh terhadap nilai perusahaan

\section{Ukuran Perusahaan Terhadap Nilai Perusahaan}

Ukuran perusahaan adalah cerminan terhadap ukuran besar atau kecil suatu perusahaan yang sering dilihat dari total aset perusahaan. "Ukuran perusahan merupakan ukuran besar kecilnya suatu perusahaan yang ditunjukan atau dinilai oleh total asset, total penjualan, jumlah laba, beban pajak dan lain-lain" (Brigham dan Houston, 2010). Investor dianggap lebih menyukai perusahaan dengan ukuran besar yakni dengan total aset besar karena perusahaan besar adalah perusahaan yang telah lama berdiri dan dirasa memiliki banyak pengalaman. Penelitian Indriyani (2017) menunjukan ukuran dapat mempengaruhi nilai perusahaan.

Hipotesis 2: Ukuran perusahaan berpengaruh terhadap nilai perusahaan. 


\section{Intellectual Capital Terhadap Nilai Perusahaan}

Intellectual capital atau sering di sebut dengan modal intelektual adalah suatu aset tidak berwujud yang mampu menciptakan keunggulan kompetitif pada perusahaan dan modal ini merupakan modal unik yang menjadi

ciri khas perusahaan sehingga sangat susah dittru oleh perusahaan lain. Intellectual capital mengacu kepada sebuah pengetahuan dan kemampuan yang dimiliki oleh suatu kolektivitas sosial seperti organisasi, praktek professional atau juga komunitas intelektual. Modal intelektual terdiri dari tiga komponen yakni modal manusia, modal konsumen dan modal organisasi. Perusahaan dengan tingkat intellectual capital yang besar dianggap mampu menciptakan kesejahteraaan terhadap perusahaan. Dalam penelitian Suparno dan Ramadini (2017) menunjukan intellectual capital mampu mempengaruhi nilai perusahaan.

Hipotesis 3: Intellectual Capital berpengaruh terhadap nilai perusahaan.

\section{METODE}

Jenis penelitian ini menggunakan jenis penelitian kuantitatif. Penelitian ini dilakukan di Bursa Efek Indonesia Universitas Kanjuruhan Malang dengan mengambil data sekunder berupa laporan keuangan dan laporan tahunan. Populasi yang digunakan dalam penelitian ini adalah perusahaan food and beverage di BEI tahun 2014-2018. Pemilihan sampel menggunakan purposive sampling sehingga didapatkan 11 perusahaan.

Variabel dependen dalam penelitian adalah nilai perusahaan yang diukur menggunakan Price Book Value (PBV):

Rasio PBV $=\frac{\text { Harga pasar perlembar saham }}{\text { Nilai buku perlembar saham biasa }}$

Variabel independen dalam penelitian adalah:

1. Profitabilitas dalam penelitian dihitung dengan menggunakan rasio Return On Equity (ROE):

$\mathrm{ROE}=\frac{\text { Laba bersih setelah pajak }}{\text { Total modal }}$

2. Ukuran perusahaan adalah besar kecilnya suatu perusahaan dengan melihat jumlah aset yang dimiliki perusahaan. Ukuran perusahaan diukur berdasarkan LN (total aset).

3. Intellectual capital diukur menggunakan value added intellectual efficiency method (VAIC ${ }^{\text {TM}) . ~}$ $(\mathrm{VAIC})^{\mathrm{TM}}=\mathrm{VACA}+\mathrm{VAHU}+\mathrm{STVA}$

Teknik analisis data yang digunakan adalah statistik deskriptif, uji asumsi klasik, analisisi regresi linier berganda dan uji hipotesis.

\section{HASIL PENELITIAN}

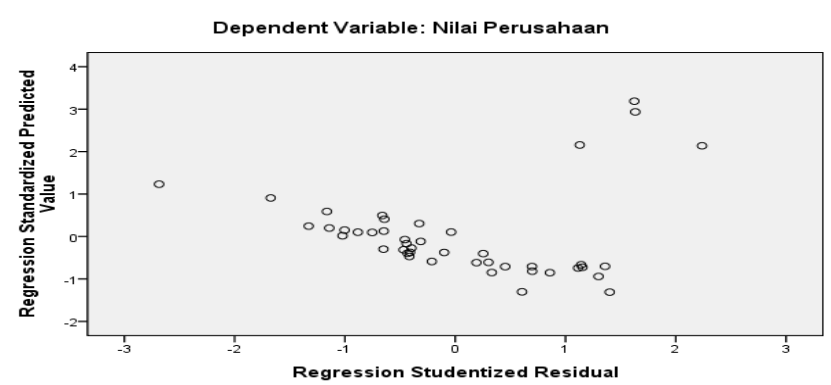

Gambar 1 Hasil Uji Heteroskedasistas

Sumber: Pengelolaan data dengan SPSS, 2019

Berdasarkan gambar 1 diketahui bahwa titik-titik menyebar secara acak serta tersebar diatas maupun dibawah angka 0 pada sumbu $\mathrm{Y}$ artinya tidak terjadi Heteroskedasistas pada model regresi. 
Tabel 1 Hasil Analisis Regresi



Sumber: Pengelolaan data dengan SPSS, 2019

Berdasarkan tabel 1 menunjukan nilai Asymp. Sig. > (0.05) pada Runs Test dan One-Sample Kolmogorov-Smirnov Test disimpulkan bahwa model regresi berdistribusi normal dan bebas dari autokorelasi. Nilai tolerance diatas 0.1 dan nilai VIF dibawah 10 untuk setiap variabel menunjukan bahwa semua variabel independen tidak terdapat korelasi antara variabel yang satu dengan lainnya.

Pada tabel 1 menunjukan secara simultan nilai Sig. di bawah 0,05, sehingga disimpulkan bahwa profitabilitas, ukuran perusahaan dan intellectual capital berpengaruh terhadap nilai perusahaan. Nilai adjusted $R$ Square sebesar 0,620 artinya sebesar 62\% nilai perusahaan dijelaskan oleh variabel profitabilitas, ukuran perusahaan dan intellectual capital dan sisanya sebesar $38 \%$ nilai perusahaan dijelaskan oleh variabel diluar penelitian. Hasil pengujian secara parsial menunjukan bahwa variabel profitabilitas mempengaruhi nilai perusahaan dengan arah negatif, ukuran perusahaan tidak mempengaruhi nilai perusahaan dan intellectual capital mempengaruhi nilai perusahaan dengan arah positif.

\section{PEMBAHASAN}

Berdasarkan hasil analisisi statistik yang sudah dilakukan diketahui variabel profitabilitas, ukuran perusahaan dan intellectual capital secara simultan berpengaruh terhadap nilai perusahaan di perusahaan food and beverage di Bursa Efek Indonesia tahun 2014-2018. Hal ini menunjukan bahwa profitabilitas, ukuran perusahaan dan intellectual capital merupakan faktor-faktor yang diperhatikan oleh investor Sedangkan hasil pengujian parsial menunjukan pengaruh dari masing-masing variabel independen terhadap variabel dependen sebagai berikut:

\section{Pengaruh Profitabilitas Terhadap Nilai Perusahaan}

Hasil penelitian menunjukkan bahwa profitabilitas berpengaruh terhadap nilai perusahaan dengan arah negatif. Hal ini mengindikasikan bahwa semakin tinggi profitabilitas tidak mampu mempengaruhi nilai perusahaan dengan baik. Hasil penelitian tidak sejalan dengan penelitian yang sebelumnya oleh Sucuahi dan Cambarihan (2016) yang menunjukan bahwa profitabilitas mampu mempengaruhi nilai perusahaan dengan arah positif.

Profitabilitas adalah ukuran kemampuan perusahaan dalam menciptakan keuntungan baik berdasarkan total aset, total modal ataupun total pembelian. Profitabilitas yang diukur dengan return on equity (ROE) atau pengembalian atas total modal bukan faktor utama investor dalam mengambil keputusan namun investor mempertimbangkan kondisi lingkungan investasi dan isu-isu yang ada.

\section{Pengaruh Ukuran Perusahaan Terhadap Nilai Perusahaan}

Hasil penelitian menunjukkan ukuran perusahaan tidak berpengaruh terhadap nilai perusahaan. Hal ini dikarenakan investor dalam melakukan investasi tidak memandang pada besar kecilnya perusahaan namun juga dari sisi laporan keuangan, nama baik dan kebijakan deviden yang ada pada perusahaan. Hasil penelitian ini tidak sejalan dengan hasil penelitian sebelumnya dari Isik, Unal dan Unal (2017). Namun, mendukung 


\section{Profitabilitas, Ukuran Perusahaan Dan Intellectual Capital Terhadap Nilai Perusahaan}

penelitian yang dilakukan oleh Chasanah (2018) yang menunjukan bahwa ukuran perusahaan tidak berpengaruh terhadap nilai perusahaan.

Ukuran perusahaan adalah cerminan terhadap ukuran besar atau kecil suatu perusahaan yang sering dilihat dari total aset perusahaan. "Ukuran perusahan merupakan ukuran besar kecilnya suatu perusahaan yang ditunjukan atau dinilai oleh total asset, total penjualan, jumlah laba, beban pajak dan lain-lain" (Brigham dan

Houston, 2010). Ukuran perusahaan bukan faktor yang dipertimbangankan bagi investor dalam melakukan keputusan investasi. Ukuran perusahaan yang besar belum bisa menjamin nilai perusahaan akan besar juga. Perusahaan harus mampu beradaptasi terhadap perubahaan dengan cepat sehingga perusahaan dituntut fleksibel terhadap lingkungan bisnisnya. Perusahaan besar biasanya adalah perusahaan yang telah berumur lama.

\section{Pengaruh Intellectual Capital Terhadap Nilai Perusahaan}

Hasil penelitian menunjukkan bahwa intellectual capital berpengaruh terhadap nilai perusahaan dengan arah positif. Hasil penelitian sejalan dengan hasil penelitian sebelumnya dari Suparno dan Ramadini (2017. Namun, tidak sejalan dengan penelitian yang dilakukan oleh Lestari (2017) yang menyatakan bahwa intellectual capital berpengaruh terhadap nilai perusahaan dengan arah negatif.

Investor indonesia diduga merespon informasi mengenai intellectual capital dengan baik karena investasi ini mampu mempengaruhi nilai perusahaan dan investor Indonesia tidak lagi menganggap bahwa intellectual capital adalah investasi yang bersifat abstrak. Intellectual capital atau sering di sebut dengan modal intelektual adalah suatu aset tidak berwujud yang mampu menciptakan keunggulan kompetitif pada perusahaan dan modal ini merupakan modal unik yang menjadi ciri khas perusahaan sehingga sangat susah dittru oleh perusahaan lain.Investor menempatkan nilai tinggi untuk suatu perusahaan dengan tingkat intellectual capital yang tinggi.

\section{KESIMPULAN}

Kesimpulan hasil penelitian secara simultan profitabilitas, ukuran perusahaan dan intellectual capital berpengaruh terhadap nilai perusahaan. Sedangkan secara parsial profitabilitas berpengaruh terhadap nilai perusahaan dengan arah negatif, ukuran perusahaan tidak berpengaruh terhadap nilai perusahaan dan intellectual capital berpengaruh terhadap nilai perusahaan dengan arah positif. Penelitian selanjutnya disarankan untuk menambah sampel penelitian yang lebih luas dan menambah faktor-faktor ekonomi yang berkaitan dengan penelitian.

\section{DAFTAR PUSTAKA}

Brigham, Eugene F. dan Joel F. Houston. (2010). Dasar-dasar Manajemen Keuangan. Buku satu. Edisi Kesebelas. Alih Bahasa Ali Akbar Yulianto. Jakarta: Salemba Empat.

Chasanah, Amalia Nur. (2018) Pengaruh Rasio Likuiditas, Profitabilitas, Struktur Modal dan Ukuran Perusahaan Terhadap Nilai Perusahaan Pada Perusahaan Manufaktur yang Terdaftar Di Bei tahun 2015-2017. Jurnal Penelitian Ekonomi dan Bisnis. Vol. 3, No. 1: 39 - 47.

Dewa, Gatot Putra, Fachrurrozie Fachrurrozie dan Nanik Sri Utaminingsih. (2014). Pengaruh Profitabilitas Terhadap Nilai Perusahaan Dengan Luas Pengungkapan CSR Sebagai Variabel Moderasi. Accounting Analysis Journal. Vol. 3, No. 1.

Indriyani, Eka. (2017). Pengaruh Ukuran Perusahaan dan Profitabilitas Terhadap Nilai Perusahaan. Jurnal Ilmu Akuntansi. Vol. 10. No. 2: 333-348.

Lestari. (2017). Pengaruh Intellectual Capital dan Kepemilikan Institusional Terhadap Nilai Perusahaan. JDEB. Vol. 14, No. 1: 17-39.

Lestari, Nanik dan Rosi Candra Sapitri. (2016). Pengaruh Intellectual Capital Terhadap Nilai Perusahaan. Jurnal Akutansi, Ekonomi dan Manajemen Bisnis. Vol. 4, No. 1. 
Profitabilitas, Ukuran Perusahaan Dan Intellectual Capital Terhadap Nilai Perusahaan

Madhani, Pankaj M. (2009). Resource Based View: Concept and Practices. India: Icfai University Press.

Nugroho, Wawan Satdyo dan Fadlil Abdani (2018). Profitabilitas, Dividend Policy, Leverage dan Keputusan Investasi Terhadap Nilai Perusahaan Konstruksi di Bursa Efek Indonesia. El-Muhasaba. Vol.8, No.1: 104-122.

Saragih, Houtmand P Saragih. (2018). Dilepas Asing, Saham Indofood Langsung Anjlok di http://m.cnbnnindonesia.com (diakses 27 Desember 2019)

Sucuahi, William dan Jay Mark Cambarihan. (2016). Influence Of Profitability To The Firm Of Disersified Companies In The Philipines. Accounting and Finance Reseach. Vol. 5, No. 2: 149-153.

Suparno dan Ristika Ramadani. (2017). Pengaruh Intellectual Capital dan Earning Pershare Terhadap Nilai perusahaan. Jurnal Manajemen dan Keuangan. Vol. 6, No. 1: 710-718. 